\title{
Building green covering for a sustainable use of energy
}

\author{
C.A. Campiotti, ${ }^{1}$ E. Schettini, ${ }^{2}$ G. Alonzo, ${ }^{3}$ C. Viola, ${ }^{1}$ C. Bibbiani, ${ }^{4}$ G. Scarascia Mugnozza, ${ }^{2}$ \\ I. Blanco, ${ }^{2}$ G. Vox ${ }^{2}$ \\ 'ENEA - Italian National Agency for New Technologies, Energy and Sustainable Economic \\ Development - Technical Unit Energy Efficiency - Agriculture Unit, Rome, Italy; ${ }^{2}$ Department of \\ Agricultural and Environmental Science, University of Bari, Italy; ${ }^{3}$ Dipartimento di Scienze Agrarie \\ e Forestali, University of Palermo, Italy; ${ }^{4}$ Department of Veterinary Science - University of Pisa, \\ Italy
}

\begin{abstract}
Nowadays the growth of the cities increased built and paved areas, energy use and heat generation. The phenomenon of urban warming, called urban heat island, influences negatively outdoor comfort conditions, pollutants concentration, energy demand for air conditioning, as well as increases environmental impact due to the demand of energy generation. A sustainable technology for improving the energy efficiency of buildings is the use of green roofs and walls in order to reduce the energy consumption for conditioning in summer and improve the thermal insulation in winter. The use of green roofs and walls can contribute to mitigate the phenomenon of heat island, the emissions of greenhouse gases, and the storm water runoff affecting human thermal comfort, air quality and energy use of the buildings. Recently, a number of municipalities started to adopt regulations and constructive benefits for renovated and new buildings which incorporate green roofs and walls. The aim of this paper is to describe the green roofs and walls plant technology.
\end{abstract}

Correspondence: Evelia Schettini, Department of Agricultural and Environmental Science, University of Bari, via Amendola 165/A - 70126 Bari, Italy. Tel. +39.080 .5443060 - Fax +39.080 .5442977 .

E-mail: evelia.schettini@uniba.it

Key words: air-conditioning, energy savings, urban ecology, green roofs, green walls.

Acknowledgements: the present work has been carried out under the "Piano triennale 2012-2014 per la Ricerca di Sistema Elettrico Nazionale, progetto C.2 'Sviluppo di modelli per la realizzazione di interventi di efficienza energetica sul patrimonio immobiliare pubblico', Piano Annuale di Realizzazione (PAR) 2012", funded by the Italian Ministry of Economic Development.

The data processing and the editorial work must be shared, within the competencies of the research groups, equivalently among the Authors.

(C) Copyright C.A. Campiotti et al., 2013

Licensee PAGEPress, Italy

Journal of Agricultural Engineering 2013; XLIV(s2):e50

doi:10.4081/jae.2013.s2.e50

This article is distributed under the terms of the Creative Commons Attribution Noncommercial License (by-nc 3.0) which permits any noncommercial use, distribution, and reproduction in any medium, provided the original author(s) and source are credited.

\section{Introduction}

The phenomenon of urban warming, known as urban heat island, influences negatively outdoor comfort conditions, pollutants concentration, as well as increases the environmental impact due to the energy demand for air conditioning (Karlessi et al., 2009; Karlessi et al., 2011; Santamouris, 2012). A sustainable technology for improving the energy efficiency of buildings is the use of green roofs and green walls in order to reduce the energy consumption for conditioning in summer and to increase the thermal insulation in winter (Cheng et al., 2010; Jim and Tsang, 2011; Köhler and Poll, 2010; Perini et al., 2011).

The technique of establishing vegetation on rooftops and facades of buildings, known as Green Roofs and Facades (GRF), has seen a growing interest in many cities. It can be considered a solution for providing insulation to buildings and thus contributing to save energy consumption by reducing energy demand for space conditioning (Pérez et al., 2011). Besides GRF can increase the life span of a typical roof by protecting the roof components from solar radiation and extreme temperatures. The elevation of the temperature in the cities (the so called urban heat island effect), due to the high concentration of heat absorbed and re-irradiated by rooftops and pavements, can be reduced by the extensive use of the GRF technique. The plants that improve the air quality in the urban areas by emitting oxygen can also remove airborne pollutants and provide a more aesthetically pleasing environment to live and work. Due to contribution which GRF give to the general topic of decrease the $\mathrm{CO}_{2}$ in the air, a widespread use of "green roofs," "living roofs,", "green facade" and "eco roofs" can become a part of the solution and an action response to the Kyoto Protocol. It is reported a worldwide surface of 234 ha of GRF, while in Italy there are about $1000 \mathrm{~m}^{2}$ of Green Roofs. Because the building sector in Europe consumes $40 \%$ of the total end-energy, there is an increasing interest in using such "green option" to improve the energy efficiency of civil buildings in Europe, and the green roofing and facades technology is to become common in the building of new construction industry. However, there is still a lack of quantifiable data to definitely account either the materials and techniques or the benefits that green roofs and facades can really provide to the efficiency and energy saving of buildings, its occupants, and the nearby community. Although data are available for some areas, mainly Germany and North America, most of them are not transferable to specific climatic conditions of other countries. Recently, ENEA has started a project using some experimental facilities available at the Centre ENEA, located at $30 \mathrm{~km}$ in the north of Rome (latitude: $42^{\circ} 02^{\prime} 36^{\prime \prime}$, longitude: $\left.12^{\circ} 18^{\prime} 28^{\prime \prime}\right)$. The priority established by the project team was to start developing a feasibility study in order to define materials, energetic parameters, adapted plant species and options for the green roofs and facades systems, and to collect existing performance data and scientific information on construction, 
maintenance, costs and plant systems. This paper is also part of a research activity in progress at ENEA to explore the potential of GRF systems as sustainable and innovative tools for improving energy efficiency by the use of "green insulation" of buildings, and their contribute to aesthetic and eco-urban life in the cities.

\section{Energy fluxes in Green Roofs and Walls}

Aim of the green wall or roof is to reduce solar energy absorbed by the wall/roof by screening the exposed surface and to increase thermal insulation; this allows the reduction of the energy demand for air conditioning used to reduce high temperatures in the warm periods.

Figure 1 shows the energy fluxes occurring in the green roof/wall system, and the symbols used in this figure are shown in Table 1. Heat is exchanged by means of conduction (C), convection (A) and radiation ( $\mathrm{E}$ in the solar range and $\mathrm{R}$ in the long wave infrared range); solar radiation $\left(E_{s}\right)$ increases energy of the whole system, thus a reduction of the

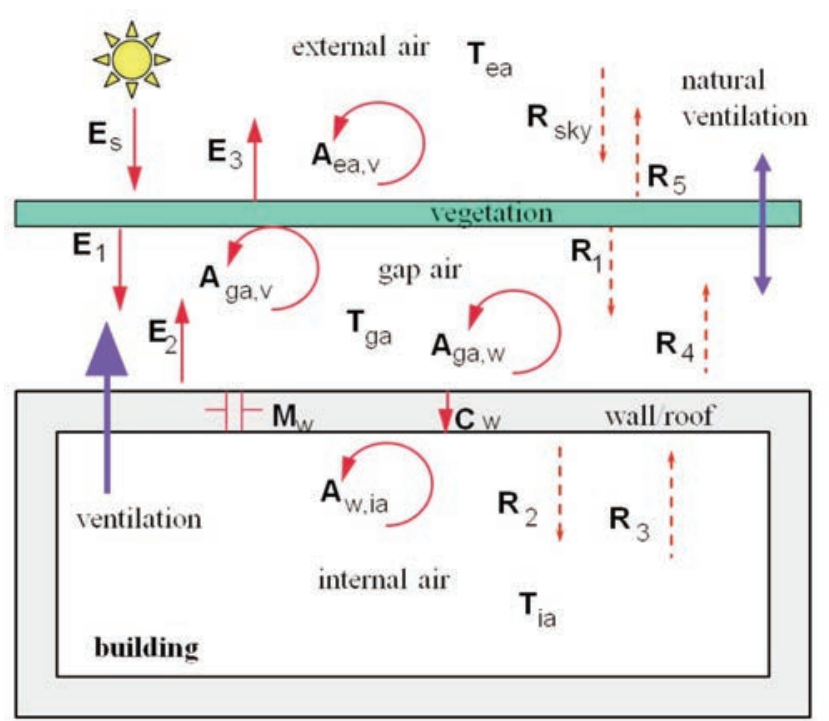

Figure 1. Energy fluxes in a green roof/wall system; symbols are described in Table 1.

\section{Table 1. List of Symbols}

\section{$\mathrm{A}=$ heat transfer by convection $[\mathrm{W}]$ \\ $\mathrm{C}=$ heat transfer by conduction $[\mathrm{W}]$ \\ $\mathrm{R}=$ heat transfer by irradiation [W] \\ $\mathrm{H}=$ heat transfer by ventilation [W] \\ $\mathrm{E}=$ incident solar radiation heat flux $[\mathrm{W}]$ \\ $\mathrm{M}=$ heat storage $[\mathrm{W}]$ \\ $\mathrm{T}=$ temperature $[\mathrm{K}]$ \\ Subscripts}

ea=external air

$\underline{\text { ga=gap air }}$

ia=external air

$s=$ solar

$\mathrm{v}=$ vegetation

$\mathrm{W}=$ wall//roof solar transmissivity of the plant wall results in a decrease of the temperature inside the building. Solar transmissivity of the plant wall mainly depends on the percentage of building surface covered with the plants. When the plants wall strongly reduces solar transmissivity, heat transfer from the plant wall to the building surface mainly occurs by convection and by long wave infrared radiation. Heat transfer by convection depends on the air velocity in the gap. Radiation heat transfer in the long wave infrared range depends on the emissivity of the surfaces; a suitable choice of the building surface emissivity can increase the thermal insulation of the building. Natural ventilation occurring through the green wall/roof, if it is permeable to the air, influences the air gap temperature and consequently the building air temperature.

\section{The design of the GRF systems}

The growing of plants either on the rooftop or on the outside walls of buildings implies that plants should be selected according to a number

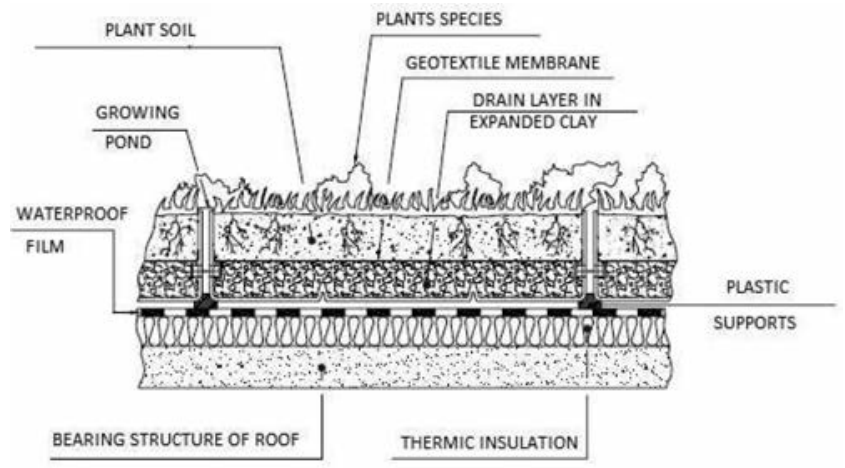

Figure 2. Detail of hydroponic substrate.

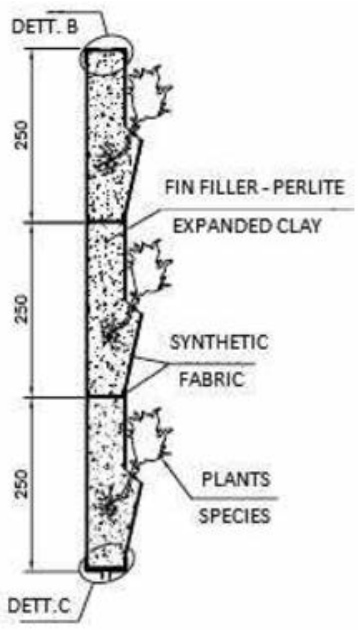

SEZIONE A-A

Figure 3. Section modular system. 
of technical considerations and parameters, e.g. plants should not modify the structural parts of buildings, plant species should be chosen to establish green coverage in a short time, plants should have high drought tolerance and finally plants should not create conflicts with local or native species and should be most suited to each aspect of the built environment. Appropriate evaluation should be done to choose what plant species are most suitable either for rooftop or for facades. Criteria for selecting plant material include design intent, aesthetic appeal, local environmental conditions, plant characteristics such as rate of establishment, longevity, disease and pest resistance, the substrate composition and depth available for planting, the eco-system service potential. Tables 2-3 report a selection of plants species that can be used for GRF and their biological characteristics (Niachou et al., 2001; Dunnet et al., 2008; Kristin et al., 2008; Trepanier et al., 2009; Blanusa et al., 2013).

Although some plants are able to grow directly on walls by taking root

Table 2. Plants species used for Green Roofs.

\begin{tabular}{|c|c|c|}
\hline Species & Family & Type or features \\
\hline Sedum sp & Crassulaceae & $\begin{array}{l}\text { Evergreen ( } 5-7 \mathrm{~cm} \text { in height). } \\
\text { Flowering in summer. } \\
\text { Mild climate, sun exposure, drought tolerance }\end{array}$ \\
\hline Dianthus sp & Caryophyllaceae & $\begin{array}{l}\text { Herbaceous plant. } \\
\text { Red and white flowers. } \\
\text { Tropical and temperate climate. }\end{array}$ \\
\hline Allium & Alliaceae & $\begin{array}{l}\text { Annual / perennial bulbous plants. } \\
\text { White, rose, violet inflorescence. } \\
\text { Temperate climate }\end{array}$ \\
\hline Achillea & Ateraceae & $\begin{array}{l}\text { Perennial herbaceous. } \\
\text { White and rose flower. } \\
\text { Sun exposition }\end{array}$ \\
\hline Arabis & Cruciferae & $\begin{array}{l}\text { Perennial herbaceous plant. } \\
\text { White flower. } \\
\text { Temperate and cold climate. }\end{array}$ \\
\hline Aster & Asteraceae & $\begin{array}{l}\text { Perennial herbaceous plant. } \\
\text { Inflorescence of different colors. } \\
\text { Temperate and cold climate. }\end{array}$ \\
\hline
\end{tabular}

Table 3. Plants species used for Green Walls.

\begin{tabular}{|c|c|c|}
\hline Species & Family & Type or features \\
\hline Hedera sp & Araliaceae & $\begin{array}{l}\text { Evergreen climbing shrub (to } 20 \mathrm{~m} \mathrm{~h} \text { ). } \\
\text { Cold and mild climate. }\end{array}$ \\
\hline Parthenocissus sp. & Vitaceae & $\begin{array}{l}\text { Deciduous climbing shrub (to } 20 \mathrm{~m} \mathrm{~h} \text { ). } \\
\text { Temperate climate. }\end{array}$ \\
\hline Bignonia capreolata & Bignoniaceae & $\begin{array}{l}\text { Evergreen climbing (to } 12 \mathrm{~m} \mathrm{~h} \text { ). } \\
\text { Mild climate. }\end{array}$ \\
\hline Clematis montana & Ranunculaceae & $\begin{array}{l}\text { Deciduous vigorous climbing (to } 10 \mathrm{~m} \mathrm{~h} \text { ). } \\
\text { Cold climate. }\end{array}$ \\
\hline Wisteria sinensis & Fabaceae & $\begin{array}{l}\text { Deciduous climbing shrub (to } 20 \mathrm{~m} \mathrm{~h} \text { ). } \\
\text { Rapid growth. Temperate climate and mild. }\end{array}$ \\
\hline Jasminus officinalis & Oleaceae & $\begin{array}{l}\text { Deciduous resistant climbing (to 6-7m h). } \\
\text { Temperate climate and sun exposure (no wind). }\end{array}$ \\
\hline Actinidia colomikta & Actinidiaceae & $\begin{array}{l}\text { Deciduous resistant shrub climbing (to } 4 \mathrm{~m} \mathrm{~h} \text { ). } \\
\text { Cold and mild climate }\end{array}$ \\
\hline Ampelopsis & Vitaceae & $\begin{array}{l}\text { Deciduous shrub climbing (to } 8 \mathrm{~m} \mathrm{~h} \text { ). } \\
\text { Temperate climate (full to partial sunlight). }\end{array}$ \\
\hline Rhyncospermum jasminoides & Apocynaceae & $\begin{array}{l}\text { Evergreen resistant climbing (to } 20 \mathrm{~m} \mathrm{~h} \text { ). } \\
\text { Temperate climate (more suitable above } 10^{\circ} \mathrm{C} \text { ). }\end{array}$ \\
\hline Adiantum $s p$ & Pteridaceae & $\begin{array}{l}\text { Perennial herb. } \\
\text { Tropical - temperate climate (shady - wetlands) }\end{array}$ \\
\hline Rododendron obtusum & Ericaceae & $\begin{array}{l}\text { Perennial sub shrubs. } \\
\text { Temperature above } 5^{\circ} \mathrm{C} \text {. }\end{array}$ \\
\hline Vriesea splendens & Bromeliaceae & $\begin{array}{l}\text { Succulent plant. } \\
\text { Tropical climate. }\end{array}$ \\
\hline Dieffenbachia picta & Araceae & $\begin{array}{l}\text { Perennial evergreen ornamental plant. } \\
\text { Tropical climate }\end{array}$ \\
\hline Dracena godseffiana & Liliaceae & $\begin{array}{l}\text { Evergreen ornamental plant (to } 2 \mathrm{~m} \mathrm{~h} \text { ). } \\
\text { Tropical climate }\end{array}$ \\
\hline
\end{tabular}


in the substance of the wall itself, it is advisable not to create conditions which could promote little deterioration in the building surface. Therefore, to grow plants on walls and buildings some kind of support structure is usually essential. Facade could incorporate structures where plants are planted or allowed to take root by structures made of cables, rope or netting, wide-meshed grid structure to which plants can be attached and trained into place, special containers planted at different levels on the facade.

Whenever possible it is advisable to leave a small gap between the facade of the building and the supporting structure in order to maximize the effects of summer cooling and winter insulation.

The design of the GRF systems must take into account the load-bearing capacity of the structure, the design of waterproofing and irrigation systems (hydroponics system) and the methods of getting soil and other necessary materials onto the roof.

Many possibilities exist for constructing of green roofs, depending on the characteristics of both buildings and local climate. Plants can be established directly upon the green roof media via seed, plugs, and cuttings or plants can be pre-grown at ground level on a blanket, mat, or tray and then placed on the roof. Both the green facades and the green roofs use a hydroponics system to grow plants. The hydroponics systems used are closed-loop systems provided with a biofiltration and nutrient recycling system, which will allow to capture, reuse and treat nutrient solutions and water (Bibbiani et al., 2011; Massa et al, 2010).

The plant grow system is fed by appropriate nutrient solution which is re-circulated from a manifold, located at the top or at the bottom of the wall, and then collected in a gutter were is filtered and recirculated to the plants. However, new building construction can include GRF systems which can use the grey water from inside the building, with significant water saving of the building's potable water use. Figure 2 and Figure 3 show the modular system under experimentation at ENEA.

\section{Conclusions}

Green roofs and facades (GRF) systems represent a class of plant technology still absent from conventional roof and walls of civil buildings but with a high potential to be used as innovative solutions for improving energy efficiency and saving in the sector of construction industry. GRF, like other constructing component and technology, can be used as a biological insulation system either for reducing energy for conditioning in summer or to increase the thermal properties of buildings in winter. In addition, these natural insulating systems can also improve the quality of air and the aesthetical impact of buildings in high constructed areas in cities, and have the potential to recreate natural ecosystem with trees, bushes and crops and thus contributing also to combat the global climatic changes by decreasing both the heat's island and the $\mathrm{CO}_{2}$ emissions in the city's centers.

\section{References}

Bibbiani C., Incrocci L., Campiotti C. A. 2011. A fast procedure to estimate hydraulic characteristics of greenhouse substrates from onestep outflow data. Acta Horticulturae 893: 979-986.

Blanusa T., Vaz Monteiro M.M., Fantozzi F., Vysini E., Li Y., Cameron R.W.F. 2013. Alternatives to Sedum on green roofs: Can broad leaf perennial plants offer better 'cooling service'? Build. Environ. 59: 99-106.

Cheng C.Y., Cheung K. K.S., Chu L.M. 2010. Thermal performance of a vegetated cladding system on facade walls. Build. Environ. 45 (8): 1779-1787

Dunnett N., Nagase A., Booth R., Grime P. 2008. Influence of vegetation composition on runoff in two simulated green roof experiments, Urban. Ecosyst. 11: 385-398

Jim C.Y., Tsang S.W. 2011. Biophysical properties and thermal performance of an intensive green roof. Build. Environ. 46 (6): 1263-1274.

Karlessi T., Santamouris M., Apostolakis K., Synnefa A., Livada I. 2009. Development and testing of thermochromic coatings for buildings and urban structures. Sol. Energy 83: 538-551

Karlessi T., Santamouris M., Synnefa A., Assimakopoulos D., Didaskalopoulos P., Apostolakis K. 2011. Development and testing of PCM doped cool colored coatings to mitigate urban heat Island and cool buildings. Build. Environ. 46: 570-576.

Köhler M., Poll P. H. 2010. Long-term performance of selected old Berlin greenroofs in comparison to younger extensive greenroofs in Berlin. Ecol. Eng. 36 (5): 722-729.

Getter K. L., Rowe D. B. 2008. Media depth influences Sedum green roof establishment, Urban. Ecosyst. 11: 361-372.

Massa D., Incrocci L., Maggini R., Carmassi G., Campiotti C.A., Pardossi A. 2010. Strategies to decrease water drainage and nitrate emission from soilless cultures of greenhouse tomato. Agric. Water Manage. 97 (7): 971-980.

Niachou A., Papakonstantinou K., Santamouris M., Tsangrassouls A., Mihalakakou G. 2001. Analysis of the green roof thermal properties and investigation of its energy performance, Energy Build. 33: 719729.

Pérez G., Rincón L., Vila A., González J. M., Cabeza L. F. 2011. Green vertical systems for buildings as passive systems for energy savings. Appl. Energy 88 (12): 4854-4859

Perini K., Ottelé M., Fraaij A.L.A., Haas E.M., Raiteri R. 2011. Vertical greening systems and the effect on air flow and temperature on the building envelope. Build. Environ. 46 (11): 2287-2294

Santamouris M. 2012. Cooling the cities - A review of reflective and green roof mitigation technologies to fight heat island and improve comfort in urban environments. Sol. Energy, http://dx.doi.org/ 10.1016/j.solener.2012.07.003

Trepanier M., Boivin M.A., Lamy M.P., Dansereau B. 2009. Green Roof and living walls, Chronica Horticulture 49 (2): 5-7. 